\title{
Hazine taşınmaz satışlarının emsal satışlarla karşılaştırılması: Trabzon İli örneği
}

\author{
H. Ebru Çolak1, Tuğba Memişoğlu Baykal2® ${ }^{\circledR}$, Nihal Genç*3® \\ ${ }^{1}$ Karadeniz Teknik Üniversitesi, Harita Mühendisliği Bölümü, Trabzon, Türkiye \\ ${ }^{2}$ Hacettepe Üniversitesi-Artvin Çoruh Üniversitesi, Harita Mühendisliği Bölümü, Ankara-Artvin, Türkiye \\ ${ }^{3}$ Giresun Üniversitesi, Harita Mühendisliği Bölümü, Giresun, Türkiye
}

\author{
Anahtar Kelimeler \\ Hazine \\ Hazine Taşınmazı \\ Tașınmaz Değerleme \\ Emsal \\ Trabzon
}

\begin{abstract}
ÖZ
Ülkemizde yaşanan taşınmaz ihtiyacının giderilmesinde hazine taşınmazları önemli bir görev üstlenmektedir. Gerçekleștirilen tasarruf faaliyetleriyle birlikte hazine taşınmazlarından elde edilen gelir, ülke bütçesine destek sağlamaktadır. Bu faaliyetlerin yürütülmesindeki temel adım hazine taşınmazlarının değerlemesidir. Değerleme çalışmalarının doğru ve objektif bir şekilde yapılması, gerçekleștirilecek olan tasarruf faaliyetleri sonucunda hazinenin hak ve menfaatlerinin korunmasını sağlayacaktır. Tüm bu gereklilikleri incelemek üzere gerçekleștirilen bu çalıșmada, Trabzon ili Ortahisar ilçesindeki hazine tașınmaz satıșları ile bunlara emsal olan taşınmaz satışları, emsal yöntemi esas alınarak karşılaştırılmıştır. Karșılaștırma sonucunda ortaya çlkan bedel farklılıklarının nedenleri, hazine ve tașınmaz değerleme kavramlarına dayanılarak her bölge için irdelenmiş ve birbirleriyle kıyaslanarak değerlendirmelerde bulunulmuştur.
\end{abstract}

\section{Comparison of treasury real estate sales and precedent real estate sales: The case study of Trabzon Province}

\author{
Keywords \\ Treasure \\ Treasury Real Estate \\ Real Estate Valuation \\ Precedent \\ Trabzon
}

\begin{abstract}
Treasury real estate plays an important role in solving the real estate needs in our country. Together with the economic activities carried out, the income obtained from the treasury real estate provides support to the country budget. The basic step in carrying out these activities is the valuation of treasury real estates. Carrying out valuation studies correctly and objectively will ensure the protection of the treasury's rights and interests in economic activities. In the study conducted to examine all of these, the sales of the treasury real estates in Ortahisar district of Trabzon province and the sales equivalent to them were compared on the basis of the precedent method. As a result of the comparison, the reasons for the price differences for each region were examined based on the concepts of treasury and real estate valuation and the regions were compared with each other.
\end{abstract}




\section{GíRIş}

Toprak, hayatımızın her alanında fazlasıyla öneme sahip olan ve üretilemeyen kıt bir kaynaktır. Günümüzün birçok üretim ve hizmet faaliyetinin şekillenmesinde kilit taşı görevi görmektedir. Ekonomi üzerinde büyük katkıları olan toprağın, artan toprak kıtlığıyla beraber gün geçtikçe değeri daha da iyi anlaşılmaktadır.

Toprak kıtlığı sorununun giderek büyümesi taşınmaz ihtiyacını da arttırmıştır. Yıllardan beridir ülkemizde yaşanan bu sorunun giderilmesinde hazine taşınmazları büyük rol oynamıștır. Özellikle Osmanlı Devleti zamanında hazine malı olan vakıf malları, devletin güvenlik hizmetleri ve yönetimi dişında kalan birçok durumda ihtiyaçlara cevap vermiştir (Çoruhlu vd. 2014:90). Günümüzde ise Türkiye'nin yüz ölçümünün büyük bir bölümünü oluşturan hazine taşınmazları; konut sorunları, çarpık kentleșme, istihdam teşviki, ekonomik ve sosyal sıkıntıların giderilmesi gibi durumlarda önemli görevler üstlenmektedir.

Devlet, hazine taşınmazlarını kamu hizmetlerine tahsis ederek ve özel mülkiyetindeki taşınmazlardan ise tasarruf faaliyetleriyle gelir elde ederek ekonomiye fayda sağlamaktadır. Bu bağlamda hazine taşınmazları, kamu malları ve hazinenin özel malları olarak iki grupta incelenmektedir. Kamu malları kamu hizmetlerine tahsis edilirken hazinenin özel malları ise getirdiği gelirle ekonomiye destek sağlamaktadır. Hazineye ait bu mallar tasarruf faaliyetleri olan edinim, yönetim ve elden çlkarma işlemleri ile devlet bütçesine gelir olarak dönebilmektedir. Tasarruf faaliyetlerinin ekonomiye en doğru şekilde katkı sağlamasında hazine taşınmazları için belirlenen bedeller büyük önem arz etmektedir.

Hazine tașınmazları için bedel belirlerken uluslararası değerleme standartlarından faydalanılarak taşınmaz değerleme çalışmaları yürütülmektedir. Alımsatım, kira, ecrimisil, kamulaştırma, irtifak hakkı, trampa vb. faaliyetler için hazine taşınmazlarının değerlemesi yapılmaktadır. Değerleme yapılırken emsal, gelir ve maliyet olmak üzere üç farklı değerleme yöntemi kullanılmaktadır. Hazine tașınmazlarının değerlemesinde en çok kullanılan yöntem emsal yöntemidir.

$\mathrm{Bu}$ çalışmada hazine taşınmazları ve tasarruf faaliyetleri hakkında bilgi verilmiş ve ardından hazine taşınmazlarının değerleme süreci anlatılmıştır. Son olarak uygulama kapsamında hazine taşınmazlarının değerlemesi sonucunda elde edilen bedellerle, anılan tașınmazlara emsal olarak alınan özel mülkiyete konu taşınmazların bedelleri karşılaştırılmış ve hazine hak ve menfaatlerinin nasıl etkilendiği incelenmiștir. $\mathrm{Bu}$ kapsamda pilot bölgeye ait 2017-2018 yıllarının İl Millî Emlak Müdürlüğünce yapılan kıymet takdir çalışmaları ve Tapu Müdürlüğünce yapılan alım satım işlemlerine esas rayiç değerleri temin edilmiştir. Elde edilen verilerde gerekli düzenlemeler yapıldıktan sonra bedellerin karşılaştırması yapılmış, ortaya çıkan farklılıkların sebep ve sonuçları irdelenmiştir.

\subsection{Hazine Taşınmazı Kavramı ve Kapsamı}

Dilimizde hazine kavramı ekonomik açıdan "devlet malının veya parasının saklandığı yer" anlamına gelirken, mali hukukumuz açısından devletin genel bütçe ile idare edilen kamu kurum ve kuruluşlarına ait olan taşınır ve taşınmaz mallarını, çeşitli haklarını, alacaklarını ve borçlarını ifade eder (Kuşgöz, 2018:2). Aynı zamanda hazine kavramı genel bütçe kapsamındaki kamu idarelerinin tüzel kişiliğini temsil etmektedir (T.C. Resmi Gazete, 2007). Öte yandan taşınmaz kavramı ise hukuki açıdan bakıldığında "bir yerden başka bir yere tașınması olanaksız mal." olarak ifade edilir. 4721 sayılı Türk Medeni Kanunu'nda taşınmaz mülkiyetinin kapsamından bahsedilir ve üç kısma ayrılır. Bunlar; "arazi, tapu kütüğünde ayrı sayfaya kaydedilen bağımsız ve sürekli haklar ve kat mülkiyeti kütügüne kayıtlı bağımsız bölümler" şeklindedir.

Hazine taşınmazı kavramı ise 327 sıra nolu Millî Emlak Genel Tebliği'ne göre "hazinenin özel mülkiyetindeki taşınmazlar ile devletin hüküm ve tasarrufu altındaki yerleri" kapsamaktadır (T.C. Resmi Gazete, 2010). Bu bağlamda hazinenin özel mülkiyetindeki taşınmazlar tapu sicilinde hazine adına tescil edilirken, devletin hüküm ve tasarrufu altındaki yerler ise mülkiyeti devlete ait olup hazine adına tapu sicilinde tescil edilmezler.

Hazine malları, merkezî yönetim kapsamındaki genel bütçeli idarelerin sahip oldukları mallar ile devletin hüküm ve tasarrufu altındaki malları kapsamaktadır. Bunlar sınıflandırmaya tabi tutulduğunda kamu malları ve hazinenin özel malları olarak iki kategori altında incelenirler (Söyler, 2005:12).

Kamu malları ve hazinenin özel malları farklı niteliklere sahiptirler. Kamu mallarının bir kısmı kamu hizmetlerine tahsis edilirken bir kısmı da kamunun doğrudan kullanımına bırakılmaktadır. Dolayısıyla hazine malları, kamu hizmetlerine kamu malı vasfiyla direkt katkı sağlamaktadır. Öte yandan hazinenin özel malları ise kamu hizmetlerine tahsis edilmez ve kamunun kullanımına bırakılmazlar. Ancak gelir getirmesi amacıyla kullanılıp kamuya dolaylı yollardan katkı sağlarlar (Söyler, 2005:14).

3402 sayll Kadastro Kanunu Madde 16'da kamu malları "Kamunun ortak kullanılmasına veya bir kamu hizmetinin görülmesine ayrllan yerlerle devletin hüküm ve tasarrufu altında bulunan sahipsiz yerler." olarak tanımlanmaktadır (T.C. Resmi Gazete, 1987). Bu bağlamda kamu malları; hizmet malları, orta mallar ve sahipsiz yerler olmak üzere üç alt sınıfa ayrılır.

Hizmet malları, kamu hizmetlerine tahsis edilip tapu siciline ilgili idareler adına tescil edilen mallardır. 3402 sayılı Kadastro Kanunu'nun 16. Maddesinin (a) bendinde "Kamu hizmetinde kullanılan...resmî bina ve tesisler..." olarak hizmet mallarından bahsedilmiş ve ayrıntılı olarak tanımlanmıştır (T.C. Resmi Gazete, 1987).

Orta mallarından 3402 sayılı Kadastro Kanunu'nun 16. Maddesinin (b) bendinde, "Mera, yaylak, kışlak, otlak, harman ve panayır yerleri gibi paralı veya parasız kamunun yararlanmasına tahsis edildiği veya kamunun kadimden beri yararlandığı belgelerle veya bilirkiși veya tanık beyanı ile ispat edilen..." şeklinde söz edilmiş ve kapsamlı olarak açıklanmıştır (T.C. Resmi Gazete, 1987).

3402 sayılı Kadastro Kanunu'nun 16. Maddesinin (c) ve (d) bendinde sahipsiz mallar detaylı bir şekilde belirtilmiştir. Maddenin (c) bendinde "Devletin hüküm ve tasarrufu altında bulunan kayalar, tepeler, dağlar 
(bunlardan çıkan kaynaklar) gibi tarıma elverişli olmayan sahipsiz yerler ile deniz, göl, nehir gibi genel sular... " ve (d) bendinde "Devletin hüküm ve tasarrufu altında bulunan ormanlar..." șeklinde sahipsiz malların kapsamı ifade edilmiştir (T.C. Resmi Gazete, 1987).

3402 sayılı Kadastro Kanunu'nun haricinde kamu malları kavramını tanımlayan birçok kanun bulunmaktadır. 5018 sayılı Kamu Mali Yönetimi ve Kontrol Kanunu'nun 3. Maddesi, 2863 sayılı Kültür ve Tabiat Varlıklarını Koruma Kanunu'nun 5. Maddesi ve 4721 sayılı Türk Medeni Kanunun 715. Maddesinde de kamu mallarından bahsedilmiștir. Bu kanunlarda yapılan açılklamalar birbiriyle farklılık göstermektedir. Fakat genel bir açıklama ile özetlenirse, kamu mallarının kamu kurum ve kuruluşları tarafindan yönetilen ve denetlenen tüm taşınmazlar olduğu söylenebilir (Aliefendioğlu vd. 2018:118).

Hazinenin özel malları, kamu malları gibi kamu hizmetine ve kamunun yararlanmasına tahsis edilmemiş olan, kamu mallarının fonksiyonlarını barındırmayan, getirmiş olduğu gelirlerle birlikte kamuya dolaylı olarak yarar sağlayan devletin tüzel kişiliğine ait mallardır.

Hazinenin özel mallarından kamunun serbest bir şekilde yararlanma hakkı ya da yetkisi yoktur. Devlet, hazinenin özel malları üzerinde bir mülkiyet hakkı sahibinin elinde bulundurduğu haklara sahiptir. Bu sebeple hazinenin özel malları özel hukuk hükümlerine tabidir (Atılgan, 2010:48).

\subsection{Hazine Taşınmazlarının Tasarruf Şekilleri}

Hazine taşınmazlarının tasarruf şekilleri; edinim, yönetim ve elden çlkarma olarak üç başlıkta incelenmektedir. Tüm bu ișlemler Çevre ve Șehircilik Bakanlığı Millı̂ Emlak Genel Müdürlüğü tarafından ilgili mevzuatlar çerçevesinde yürütülmektedir.

Devlet, hazine adına kamuya karşı görev ve hizmetlerini yerine getirebilmek için ihtiyaç hâlinde taşınır ve taşınmaz mal edinebilmektedir. Edinim işlemleri; satın alma, kamulaştırma, trampa, arsa-kat karşılığı inşaat, bağış, protokol kapsamında yaptırılan işler vb. faaliyetlerdir. Yönetim işlemleri kapsamında; hazineye ait taşınmazların tespiti, tahsis, kiraya verme, ecrimisil, irtifak hakkı tesis edilmesi, kullanma izni ve ön izin çalışmaları gerçekleştirilmektedir. Hazine taşınmazlarının elden çıkarılması işlemlerinde ise satış, devir ve terk faaliyetleri yürütülmektedir. Tablo 1'de gerçekleştirilen tasarruf faaliyetleri ve bunlarla ilgili mevzuatlar görülmektedir.

\section{YÖNTEM}

\subsection{Hazine Taşınmazlarının Değerlemesi}

Taşınmaz değerleme; taşınmazın fiziki koşullarının, sağladığı faydanın, taşınmaza ait arz-talep dengesinin, taşınmazı etkileyen ekonomik ve sosyal faktörlerin, taşınmazın niteliğinin ve diğer içsel-dışsal faktörlerin objektif bir şekilde teknik olarak incelenerek söz konusu taşınmaz bedelinin takdir edilmesi ișlemidir. Resmî, gerçek, özel, tüzel kişi ve kamu kurum ve kuruluşlarına ait taşınmazların, gerektiğinde uzman kişiler tarafından uluslararası değerleme standartları gözetilerek objektif bir şekilde değerleri belirlenebilmektedir. Bu bağlamda hazineye ait taşınmazların da hazinenin edinim, yönetim ve elden çlkarma işlemlerinde yürütmüş olduğu faaliyetler uyarınca bedel tespitlerinin yapılması gerekmektedir. Bedel tespitleri yapılırken taşınmaz değerleme yöntemleri kullanılmaktadır. Genel olarak kullanılan yöntemler emsal, gelir ve maliyet yöntemleridir. Bu yöntemlerden hangisinin kullanılacağı taşınmazın niteliğine bağlı olarak değişmektedir.

Tablo1. Tasarruf faaliyetlerinin gerçekleștirilmesinde yararlanılan mevzuatlar

\begin{tabular}{|c|}
\hline \\
\hline \\
\hline $\begin{array}{l}\text { Satın Alma } \\
\text { - } 6183 \text { sayılı Amme Alacaklarının Tahsil Usulü Hakkında } \\
\text { Kanun } \\
\text { Kamulaştırma } \\
\text { • } 2942 \text { sayılı Kamulaştırma Kanunu } \\
\text { Trampa } \\
\text { - } 2886 \text { sayılı Devlet İhale Kanunu } \\
\text { - } 4706 \text { sayılı Hazineye Ait Taşınmaz Malların } \\
\text { Değerlendirilmesi ve Katma Değer Vergisi Kanununda } \\
\text { Değişiklik yapılması Hakkında Kanun } \\
\text { - } 2863 \text { sayılı Kültür ve Tabiat Varlıklarını Koruma } \\
\text { Kanunu } \\
\text { - } 2942 \text { Sayılı Kamulaştırma Kanun } \\
\text { Arsa-Kat Karşılığı İnşaat } \\
\text { - } 298 \text { sira sayılı Millî Emlak Genel Tebliği } \\
\text { - Hazine Taşınmazlarının İdaresi Hakkında Yönetmelik } \\
\text { - } 2886 \text { saylı Devlet İhale Kanunu } \\
\text { Bağış } \\
\text { - } 327 \text { sıra nolu Millî Emlak Genel Tebliği }\end{array}$ \\
\hline \\
\hline $\begin{array}{l}\text { Tahsis } \\
\text { - Kamu İdarelerine Ait Taşınmazların Tahsis ve Devri } \\
\text { Hakkında Yönetmelik } \\
\text { Kira } \\
\text { - } 2886 \text { sayılı Devlet İhale Kanunu } \\
\text { - } 6098 \text { sayılı Borçlar Kanunu } \\
\text { - 300, 358, 372,379, 387, } 393 \text { sıra nolu Millî Emlak } \\
\text { Genel Tebliğleri } \\
\text { - Hazine Taşınmazlarının İdaresi Hakkında Yönetmelik } \\
\text { Ecrimisil } \\
\text { - Hazine Taşınmazları İdaresi Hakkında Yönetmelik } \\
\text { - } 336 \text { Sira Sayılı Millî Emlak Genel Tebliği } \\
\text { Ön izin, Kullanma İzni ve İrtifak Hakkı Tesisi } \\
\text { - } 4721 \text { sayılı Türk Medeni Kanunu } \\
\text { - } 324 \text { sıra nolu Millî Emlak Genel Tebliği } \\
\text { - Hazine Taşınmazlarının İdaresi Hakkında Yönetmelik } \\
\text { - Özel kanunlar }\end{array}$ \\
\hline \\
\hline $\begin{array}{l}\text { Satış } \\
\text { - } 2886 \text { sayılı Devlet İhale Kanunu } \\
\text { - Hazine Taşınmazlarının İdaresi Hakkında Yönetmelik } \\
\text { - } 313 \text { sayılı Millî Emlak Genel Tebliği } \\
\text { - } 4562,4721,5279,3385,3646,189,1164,5393 \text { ve } \\
2942 \text { sayılı bazı özel kanun hükümleri } \\
\text { Devir } \\
\text { - Kamu İdarelerine Ait Taşınmazların Tahsis ve Devri } \\
\text { Hakkında Yönetmelik } \\
\text { Terk } \\
\text { - } 203 \text { sıra nolu Millî Emlak Genel Tebliği }\end{array}$ \\
\hline
\end{tabular}

Kaynak: Faaliyet Raporu, 2019; Faaliyet Raporu, 2018; Hazine Taşınmazlarının Kiraya Verilmesi İșlemleri El Rehberi, 2018; T.C. Resmi Gazete, 2006 
Hazine malları ile ilgili faaliyetlerden Çevre ve Șehircilik Bakanlığl alt birimi olan Millî Emlak Genel Müdürlüğü sorumludur. Bu kapsamda, en yakın tarihte hazırlanmış olan 2019 yılı faaliyet raporlarına göre hazineye ait 281.980.634.406 m2 yüzölçümlü toplamda 4.241.173 adet taşınmaz Millî Emlak Genel Müdürlüğü mesuliyeti altındadır.

Millî Emlak Genel Müdürlüğü; hazine taşınmazlarının tasarruf işlemleri kapsamında yapılan satış, kamulaştırma, kira, ecrimisil, trampa, arsa-kat karşılığ inşaat, ön izin, kullanım izni ve irtifak hakkı tesisi gibi işlemlere esas olacak bedelleri taşınmaz değerleme faaliyetleri ile belirlemektedir. Değerleme faaliyetleri kapsamında bedel tespit sürecinin yürütülmesi için Millî Emlak Genel Müdürlüğü tarafından Çevre ve Şehircilik Uzmanları görevlendirilmektedir (Faaliyet Raporu, 2019:98).

Hazine taşınmazlarının bedel belirleme çalışmaları için yapılacak tüm faaliyetlerde 2014/1 sıra nolu Hazine Taşınmazlarının Değerleme İşlemleri konulu genelge esas alınmaktadır (Milli Emlak Genel Müdürlügüü 2014). $\mathrm{Bu}$ genelgeden yararlanılarak değerleme sürecinde yapılması gereken çalışmalar gerçekleștirilmekte ve bir taşınmazın değerleme günündeki güncel alım-satım bedeli olan rayiç bedel belirlenmektedir.

Hazine Tașınmazlarının Değerleme İşlemleri konulu genelgeye göre değerleme süreci dört adımdan oluşmaktadır. Bunlar; ön hazırlık, saha çalışması, en etkili ve verimli kullanım analizi ve değerleme yöntemlerinin seçimi ve uygulanmasıdır. Tüm bu adımlar tamamlandıktan sonra elde edilen verilerin analizi ve değerlendirilmesiyle taşınmaz bedeli elde edilmektedir. Ön hazırlı sürecinde kapsamlı bir araștırma yapılarak taşınmaza ait veri ve bilgiler temin edilmektedir. Saha çalışması sürecinde ise taşınmaz mahalline gidilerek taşınmaza ait tüm özellikler detaylı bir şekilde belirlenmektedir. En etkin ve verimli kullanım analizinde; taşınmazın fiili durumu, tapu kütügü ve imar durumuna ait bilgiler detaylı bir şekilde analiz edilerek bedeli etkileyen durumlar tespit edilmektedir. Ardından elde edilen tüm bu bilgiler işlenmekte ve son haline getirilerek değerleme raporu olarak sunulmaktadır.

\subsection{Değerleme Yöntemlerinin Seçimi ve Uygulanması}

Uluslararası değerleme standartlarına göre emsal, gelir ve maliyet yöntemi olmak üzere üç ana değerleme yöntemi bulunmaktadır. Hazine taşınmazlarının değerlenip rayiç bedellerinin bulunması için yapılan çalışmalarda da bu yöntemler kullanılmakta ve genellikle emsal yöntemi tercih edilmektedir.

\subsubsection{Emsal (Karşılaştırma) Yöntemi}

Emsal yöntemi hazine taşınmazlarının değerlemesinde en çok kullanılan yöntemdir. Karşılaştırma yöntemi olarak da adlandırılan bu yöntemle, değerlemesi yapılacak olan taşınmaza emsal teşkil edebilecek taşınmazların satış bedelleri göz önüne alınarak bedel tespiti ve takdiri yapılmaktadır. $\mathrm{Bu}$ bağlamda, değerlemeye konu olan taşınmazla benzer özelliklere sahip taşınmazlar bulunur ve bu taşınmazlar arasında her yönden karşılaştırma yapılır.
Karşılaştırmanın sonunda elde edilen farklılıklardan yola çıkılarak yapılan gerekli düzeltmelerle birlikte değerlemeye konu taşınmazın bedel tespiti yapılmaktadır.

Yöntemin uygulanmasında ilk olarak değerlemesi yapılacak olan taşınmaza emsal olabilecek taşınmazlar belirlenir. $\mathrm{Bu}$ belirleme yapılırken değerlemeye konu taşınmazla konum olarak aynı bölgede olması, fiziksel ve ekonomik özellikler açısından benzer olması ve mülkiyet hakları ile imar verileri yönünden karşılaştırılabilir olmasına dikkat edilir. Emsal taşınmazlar belirlendikten sonra bunlar hakkında bilgiler toplanır, muvazaalı durumların yaşanmaması adına doğruluğu kontrol edilir. Bilgi elde etme sürecinde yararlanılabilecek kaynaklar; tapu idaresi, millî emlak satışları, bilirkişiler, bilirkişi raporları, internet ilanları, icra satışları, gayrimenkul değerleme raporları, değerleme yapmış olan idarelerin çalışmaları olabilmektedir.

Değerlemeye konu taşınmaza bulunduğu konumun çevresinden emsal bulunamaması halinde, en yakın konumdan emsal satış verileri temin edilebilmektedir. Veriler temin edildikten sonra değerleme konusu taşınmaza; konum olarak yakın olan ya da yakın değilse değerleri arasında göreli bir bağ kurulan, nitelik yönünden eș, yapılaşma koşulları aynı ya da göreli olarak bağ kurulabilecek, tarım arazisi vasıflı taşınmazlar için de olanakların benzer olduğu emsaller seçilmektedir.

Elde edilen tüm veriler ışığında yöntem uygulamaya koyulur ve değerlemeye konu taşınmaz ile emsal taşınmazlar arasında karşılaştırma yapılır. Taşınmazlar karşılaştırılırken imar durumları, nitelikleri, imar planındaki konumları ve kullanım türleri, inşaat izni bilgileri, üzerlerinde yapı olup olmaması, sokak-bulvarcadde cephelerinin özellikleri, jeolojik ve topoğrafik yapısı, ulaşım olanakları, sosyal ve kültürel alanlara olan uzaklıkları, merkeze uzaklıkları, alt yapı olanakları, üzerlerinde değeri etkileyebilecek irtifak vb. takyidatların olup olmadığı, tercih edilen bir bölgede olup olmamaları, emlak rayiç değerleri gibi durumlara ait bilgiler analiz edilir. Analiz neticesinde benzerlikler ve farklılıklar detaylı bir biçimde ortaya koyulur. Belirlenen farklılıkların değer üzerindeki etkisini gösterebilmek amacıyla ağırlıklandırma yoluna gidilir ve bedele dönüştürülmesi sağlanır. Tüm bu çalışmaların neticesinde güncel piyasa koşulları da dikkate alınarak emsal satışların bedelleri değerleme tarihine uyarlanmakta ve temin edilen diğer tüm veriler göz önüne alınarak değerleme konusu taşınmazın bedel takdiri yapılmaktadır.

$\mathrm{Bu}$ yöntemde elde edilen sonuçların güvenilir olabilmesi için değerlemeye konu taşınmaz ile emsal taşınmazların özelliklerinin olabildiğince benzer olması gereklidir. Tamamen farklı özelliklere sahip olan taşınmazlar karşılaştırılmamalıdır (Yomralığlu vd. 2011:12). Değerlenecek taşınmazın türü ne olursa olsun yöntemi kullanabilmek için yeterli veriye ulaşılabildiği takdirde bu yöntem en elverişli yaklaşımdır (Karaca, 2008:43). Fakat gerekli verilerin az olması veya farklılık arz eden bilgilerin çok olması gibi durumlarda bu yöntemin kullanımı kısıtlanabilir (Yılmaz, 2019:89). Ek olarak değerlemeyi yapacak olan değerleme uzmanının bilgi ve tecrübesi de sonuçları etkileyecektir. Doğru sonuçlar için güvenilir verinin yanında değerleme yapan 
kişinin bu konuda uzman olması büyük önem arz etmektedir.

\subsubsection{Gelir Yöntemi}

Gelir yönteminde değerlenecek taşınmazın net gelirinin değerleme gününe biriktirilmesi temel alınmaktadır (Tanrıvermiş, 2017:179). Belirlenen net gelir, kapitalizasyon faiz oranı ile indirgenerek bedel takdiri yapılmaktadır. Bu yöntem genellikle sürekli olarak gelir getiren taşınmazların değerlemesinde kullanılmaktadır.

\subsubsection{Maliyet Yöntemi}

Maliyet yöntemi genellikle üzerinde yapı ya da muhdesat olan taşınmazların değerlemesinde kullanılmaktadır. Yöntem kullanılırken her sene resmi gazetede yayımlanan Yapı Yaklaşı Maliyetleri tablolarından faydalanılır. Değerleme yapılırken yapının özellikleri ve yıpranma payı göz önüne alınarak yapı bedelleri bulunmaktadır. Bulunan bedel, zemin bedeline eklenerek taşınmaz bedeli elde edilmektedir.

\section{YAPILAN ÇALIŞMA}

Bu çalışmanın amacı, hazine taşınmazlarının bedelleri ile emsal taşınmaz bedellerinin karşılaştırılarak hazinenin hak ve menfaatlerinin nasıl etkilendiğini irdelemektir. Trabzon ili Ortahisar ilçesi çalışma alanı olarak seçilmiștir. İncelenmek üzere Trabzon İl Millî Emlak Müdürlüğünden üç adet hazine taşınmazına ait bedel tespit raporları ile satış bedelleri temin edilmiştir. Trabzon Ortahisar Tapu Müdürlüğünden de seçilen 3 emsal taşınmaza ait satış bilgileri elde edilmiştir.
Birinci inceleme bölgesi olan Sayvan Mahallesi, kent merkezine uzak bir mesafede olup șehrin güneydoğu kısmında ve ilçe sınırındadır. Kent merkezine olan uzaklığa bağlı olarak buradaki taşınmazların sosyokültürel olanaklara erişimi kısıtlıdır.

İkinci inceleme bölgesi olan Cumhuriyet Mahallesi kent merkezindedir. Hem sosyokültürel hem de ulaşım ve alt yapı olanaklarına sahip bir bölgedir. Burada incelenen taşınmazlar ana yol üzerinde olmakla beraber şehrin en merkezi konumundadırlar.

Üçüncü inceleme bölgesi olan Yenicuma Mahallesi, kent merkezindedir. Sosyokültürel olanaklarla birlikte ulaşım ve alt yapı olanaklarına sahip bir bölgedir. İncelenen hazine taşınmazının ana yola, emsal taşınmazın da tali yola cephesi bulunmaktadır. Çalışma alanı ve inceleme yapılan mahalleler Şekil 1'de görülmektedir.

\subsubsection{Sayvan Mahallesinde Yapılan İnceleme}

İlk olarak Sayvan Mahallesindeki mülkiyetinin tamamı hazineye ait olan 338,94 m2 yüzölçümlü 111 nolu ada 25 nolu parsel incelenmiștir (Şekil 2 ve Şekil 4). Parsel üzerinde sağlık evi lojmanının bulunduğu tespit edilmiştir. Tahmin edilen bedel tespit raporuna göre hazine taşınmazının bedelinin 61.593 TL olarak tespit edildiği, m2 bedelinin 40 TL olduğu anlaşılmıştır. Bu verilere göre zemin bedeli 13.557,60 TL, muhdesat bedeli ise 48.035,40 TL olmaktadır. Arsa bedeli taşınmaz bedelinin \%22,01'ine denktir. Bedel belirlemelerinden sonra taşınmazın 26.12.2017 tarihinde açık ihale ile satış yoluyla 98.000 TL'ye satıldığı belirlenmiştir.

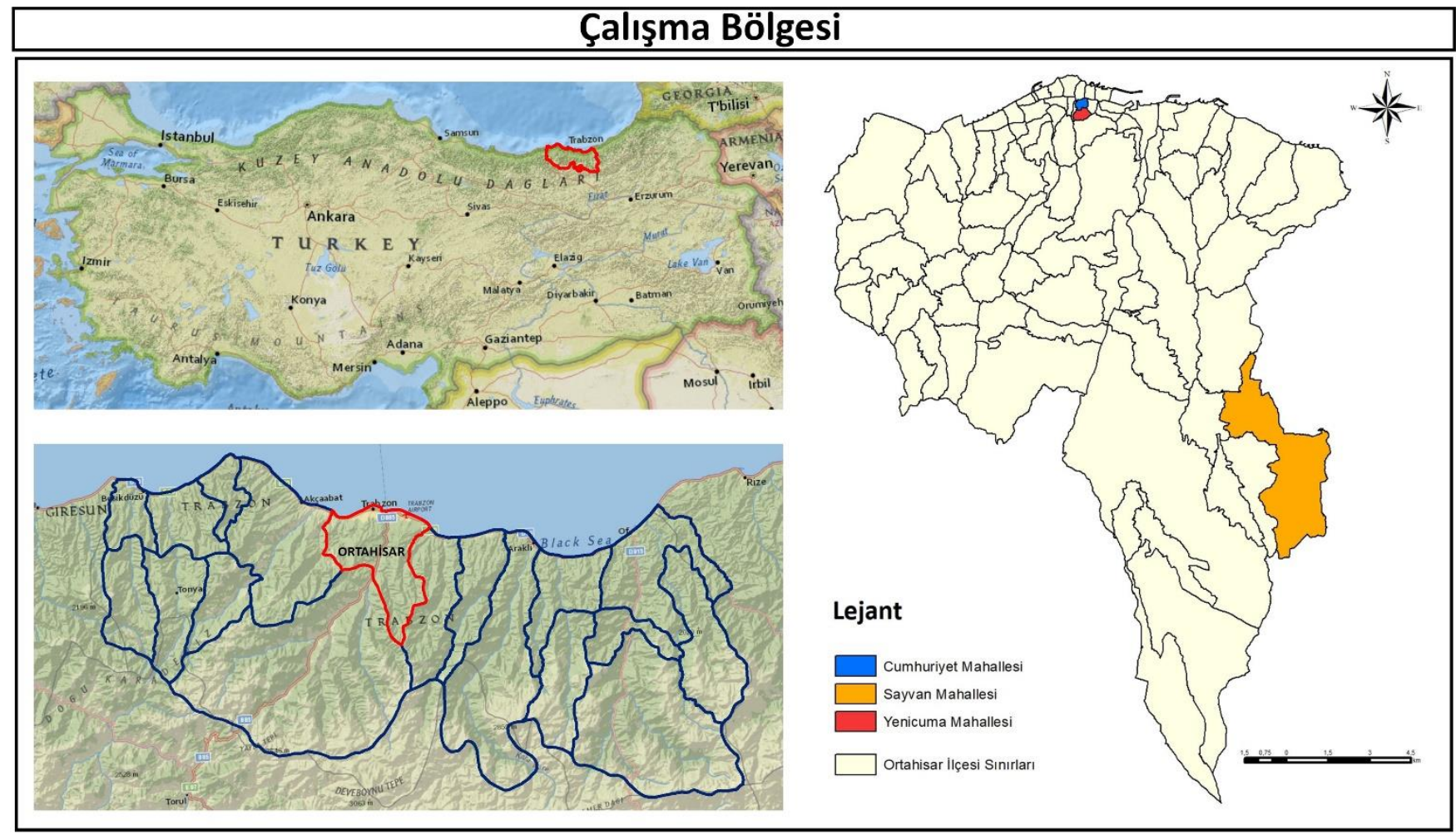

Şekil 1. Çalışma bölgesi 


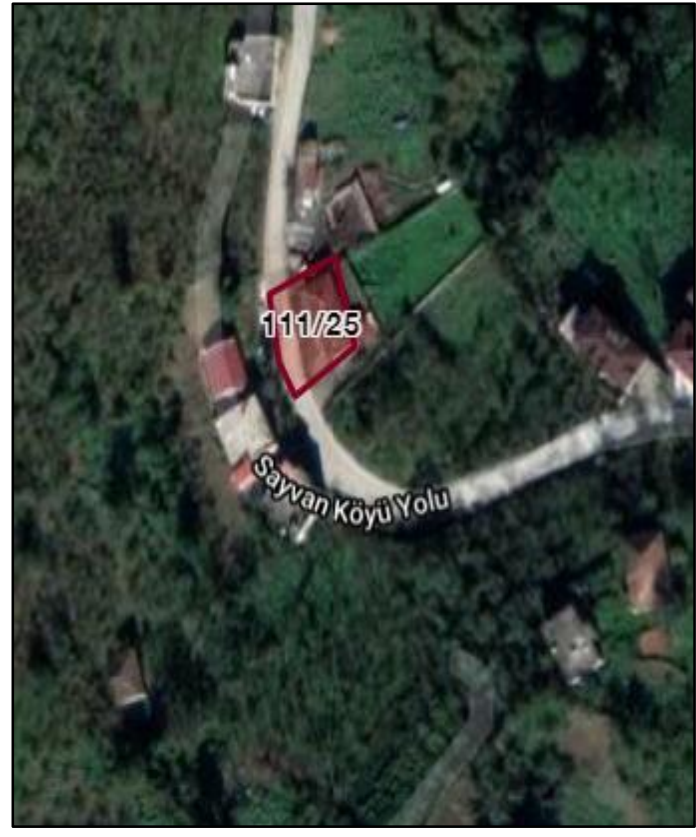

Şekil 2. 111/25 nolu hazine taşınmazının uydu görüntüsü

Kaynak: https://parselsorgu.tkgm.gov.tr

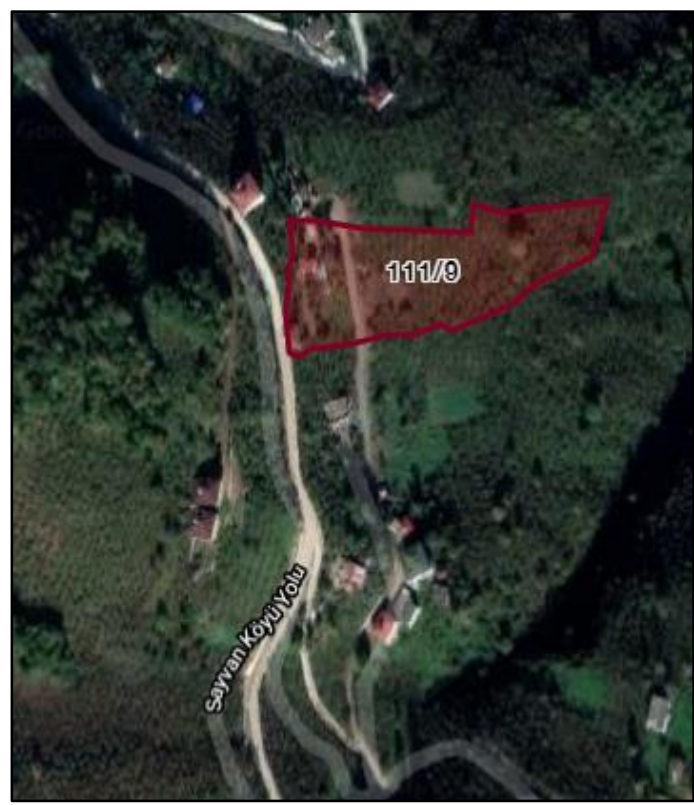

Şekil 3. 111/9 nolu emsal taşınmazın uydu görüntüsü Kaynak: https://parselsorgu.tkgm.gov.tr

$\mathrm{Bu}$ taşınmaza yine aynı mahallede $6.561,57 \mathrm{~m}^{2}$ yüz ölçümlü 111 nolu ada 9 nolu parselin 2018 yılında yapılan 1/3 hisse satışı $\left(2.187,19 \mathrm{~m}^{2}\right)$ emsal olarak alınmıștır (Şekil 3 ve Şekil 5). Emsal taşınmaz $\mathrm{m}^{2}$ bedeli 22,86 TL olmak üzere 50.000 TL'ye satılmıștır.

Karşılaştırmanın yapılabilmesi için 2017 yılında açık ihale yoluyla satılan hazine taşınmazının 2018 yılı için fiyatı 2018 yılı yeniden değerleme oranı $(\% 14,47)$ kullanılarak hesaplanmıștır. Hesap sonucunda hazine taşınmazının 2018 yılı satış bedeli 112.180,60 TL olarak bulunmuștur. Hazine tașınmazının arsa bedelinin taşınmaz bedelinin \%22,01'i olduğu hesabına dayanılarak hazine taşınmazının 2018 yılı arsa bedelinin 24.690,95 TL, $\mathrm{m}^{2}$ bedelinin ise $72,85 \mathrm{TL}$ olduğu hesaplanmıștir.

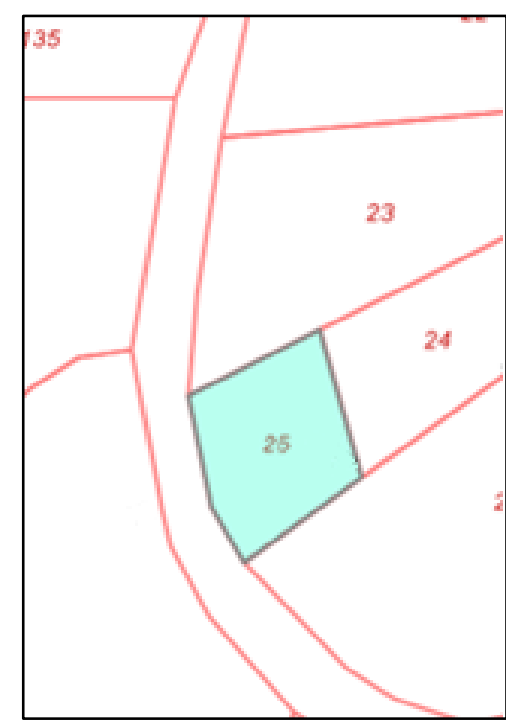

Şekil 4. $111 / 25$ nolu hazine tașınmazının imar planı kesiti

Kaynak: https://kbs.trabzonortahisar.bel.tr/imardurumu/

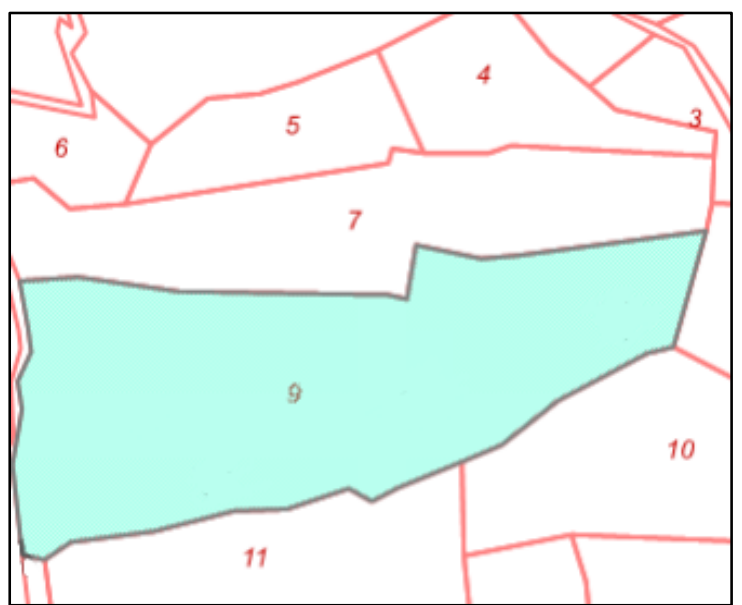

Şekil 5. 111/9 nolu emsal taşınmazın imar planı kesiti Kaynak: https://kbs.trabzonortahisar.bel.tr/imardurumu/

Eldeki verilerden hareketle hazine taşınmazının 72,85 TL olan 2018 yılı $\mathrm{m}^{2}$ satış bedelinin, 2018 yılında satılan emsal tașınmazın 22,86 TL olan $\mathrm{m}^{2}$ satıș bedelinden \%218,68 fazla olduğu belirlenmiştir. Tablo 2 'de incelenen hazine ve emsal taşınmazlarına ait bilgiler görülmektedir.

Tablo 2. Sayvan Mahallesindeki Hazine ve Emsal Taşınmazın Satış Bilgileri

\begin{tabular}{lcc}
\hline \multicolumn{1}{c}{ Bilgiler } & $\begin{array}{c}\text { Hazine } \\
\text { Taşınmazı }\end{array}$ & $\begin{array}{c}\text { Emsal } \\
\text { Taşınmaz }\end{array}$ \\
\hline Mahalle & Sayvan & Sayvan \\
\hline Ada No & 111 & 111 \\
\hline Parsel No & 25 & 9 \\
\hline Toplam Yüz ölçüm (m²) & 338,94 & 6561,57 \\
\hline Satılan Hisse & Tamamı & $1 / 3$ \\
\hline Satılan Yüzölçüm & 338,94 & 2187,19 \\
\hline Emlak Rayiç Değeri (TL) & 10 & 10 \\
\hline Satış Yılı & 2017 & 2018 \\
\hline Satış Usulü & Açık İhale & Tapu Satış \\
\hline Yeniden Değerleme (\%) & 14,47 & \\
\hline $\begin{array}{l}\text { 2018 yılı m } \\
\text { Birim Bedeli (TL) }\end{array}$ & 72,85 & 22,86 \\
\hline
\end{tabular}


Yapılan değerlendirmeler sonucunda hazine ve emsal taşınmaza ait bilgiler incelenmiştir. Hazine taşınmazının tamamı, emsal tașınmazın ise üçte bir hissesi satıșa konu olmuștur. Hem hazine tașınmazı hem de emsal tașınmaz kent merkezinden uzaktır. Bulundukları mahallede ise hazine taşınmazı mahalle merkezine yakınken emsal taşınmaz uzak kalmaktadır. Her iki tașınmaz mücavir alan sınırları içinde fakat imar planı dışındadır. Ulaşım olanaklarına erişimleri mevcuttur fakat sosyokültürel olanaklara erişimleri kısıtlıdır. Aynı zamanda belediye hizmetlerine erișimleri sınırlıdır. Hazine taşınmazının üzerinde yapı (sağlık evi lojmanı) mevcutken, emsal taşınmaz üzerinde yapı bulunmamaktadır. Emlak rayiç değerleri aynı yola cephelerinin olması ve aynı lokasyonda olmalarından ötürü eşit ve 10 TL'dir.

Tüm bu bilgiler ışığında karşılaştırma yapıldığında hazine tașınmazının $\mathrm{m}^{2}$ bedelinin emsal tașınmazın $\mathrm{m}^{2}$ bedelinden yüksek olmasının nedeninin, hazine taşınmazının mahalle merkezine daha yakın olmasından kaynaklanabileceği ve buna ek olarak üzerinde yapı olmasından ötürü yapı bedeli de satış bedeline eklendiğinde hazine taşınmazının fiyatının arttığı sonuçlarına varılmıştır. Aynı zamanda hazine taşınmazının açık ihale yoluyla satılmış olması da rekabetten ötürü fiyatı arttırmıştır. Bu çıkarımlar fiyat artıșına neden olan temel unsurlardır. Tașınmazların diğer özellikleri kıyaslandığında her iki taşınmaza da eşit derecede etki ettiklerinden ötürü bedele de eșit derecede katkı sağladıkları sonucuna varılmıştır. Hazine taşınmazının 2017 yılında satılmış olması ve 2018 yılında satılan emsal taşınmazla karşılaştırılırken fiyatının güncellenmesi gerekliliği de hazine taşınmazının $\mathrm{m}^{2}$ bedelini arttıran diğer bir unsurdur. Öte yandan taşınmazın tamamının veya belli bir miktar hissesinin satıșa konu olması da fiyatı etkileyen bir unsur olabilir. Son olarak emsal tașınmazın değerinin bir uzman kişi tarafından belirlenmemesi de bedeller arasındaki büyük farkın nedeni olabilir.

\subsubsection{Cumhuriyet Mahallesinde Yapılan İnceleme}

Cumhuriyet Mahallesi'nde 2123/9216 hissesi (39,64 $\mathrm{m}^{2}$ ) hazineye ait olan 208 ada 45 nolu parsel incelenmiştir (Şekil 6 ve Şekil 7). Bu taşınmazın 07.03.2017 tarihindeki tahmin edilen bedel tespit raporuna göre taşınmaz bedeli $\left(39,64 \mathrm{~m}^{2}\right) 523.248 \mathrm{TL}$ ve $\mathrm{m}^{2}$ bedeli 13.200 TL olarak belirlenmiștir.

Taşınmaz üzerinde muhdesat bulunmamaktadır. Hissedarı bu hazine taşınmazını doğrudan satış yoluyla 2017 yllında edinmiştir.

Hazine taşınmaz satışı ile emsal taşınmaz satışının karşılaştırılabilmesi için hazine taşınmazının 2017 yılına ait bedeli 2018 yılı yeniden değerleme oranı $(\% 14,47)$ ile hesaplanarak 2018 yılına ait taşınmaz bedeli 598.961,99 $\mathrm{TL}, \mathrm{m}^{2}$ bedeli ise 15.110,04 TL olarak bulunmuştur.

Hazine tașınmazına hemen yanında bulunan 208 nolu ada 44 nolu parselin 2018 yılında yapılan 1/2 hisse satışı $\left(83,47 \mathrm{~m}^{2}\right)$ emsal olarak alınmıştır (Şekil 6 ve Şekil 8). Eldeki verilerden hareketle hazine taşınmazının 15.110,04 TL olan 2018 yılı $\mathrm{m}^{2}$ satıș bedelinin, 2018 yılında satılan emsal taşınmazın 9.584,28 TL olan $\mathrm{m}^{2}$ satış bedelinden \%57,65 fazla olduğu belirlenmiştir. Incelenen hazine ve emsal taşınmazlarına ait bilgiler Tablo 3'te görülmektedir.

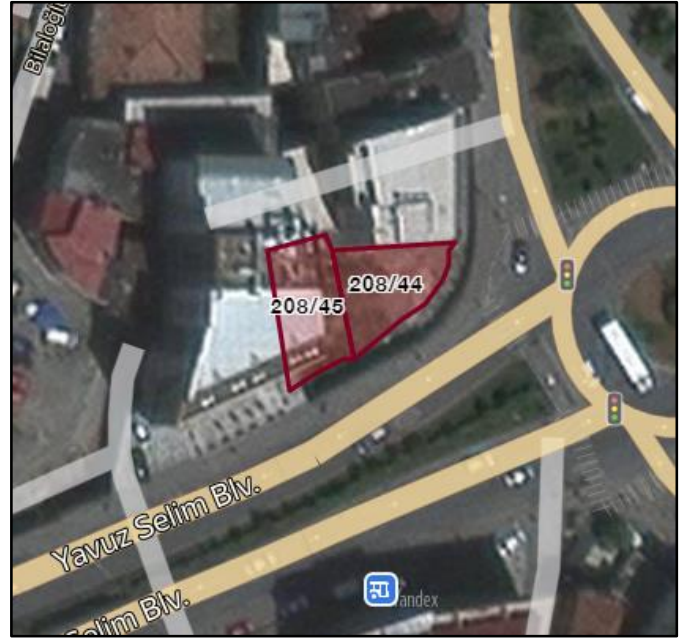

Şekil 6. $208 / 45$ nolu hazine ve $208 / 44$ nolu emsal taşınmazlarının uydu görüntüsü

Kaynak: https://parselsorgu.tkgm.gov.tr

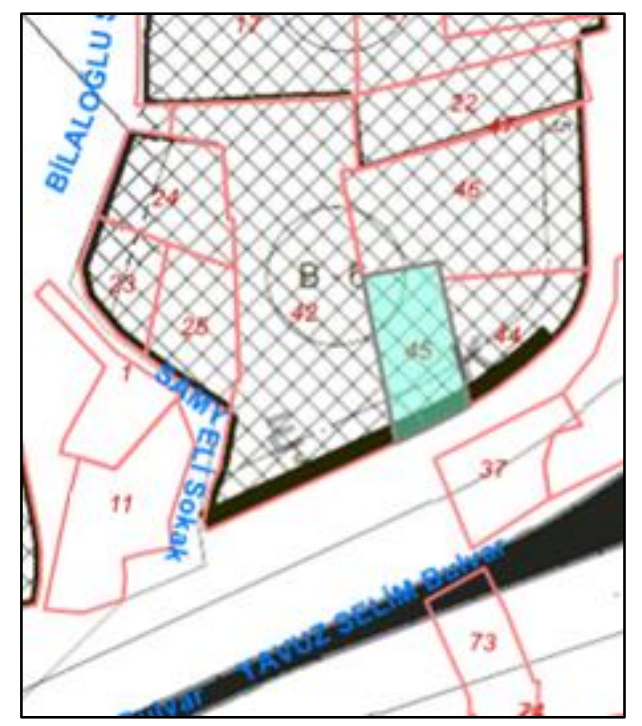

Şekil 7. 208/45 nolu hazine taşınmazının imar planı kesiti

Kaynak: https://kbs.trabzonortahisar.bel.tr/imardurumu/

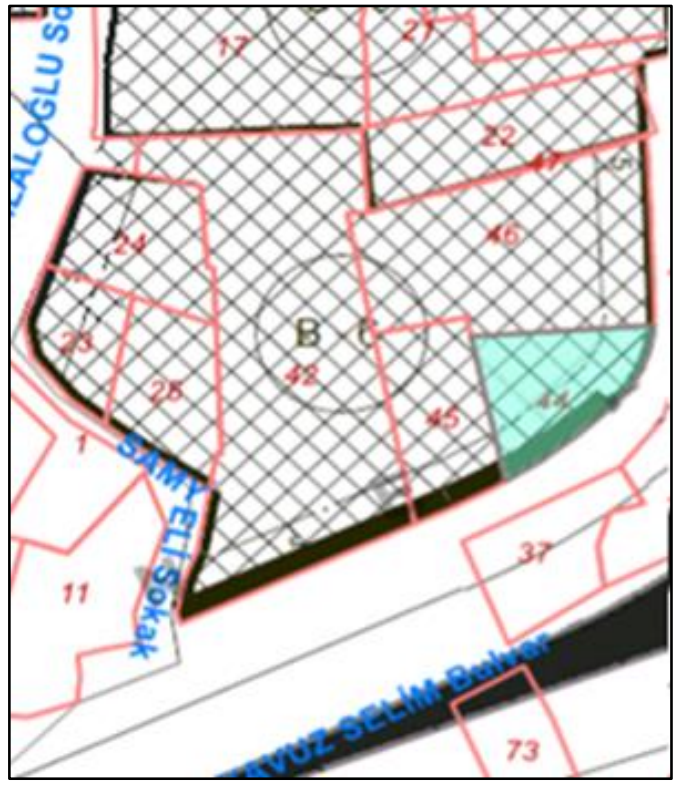

Şekil 8. 208/44 nolu emsal taşınmazının imar planı kesiti

Kaynak: https://kbs.trabzonortahisar.bel.tr/imardurumu/ 
Tablo 3. Sayvan Mahallesindeki Hazine ve Emsal Taşınmazın Satış Bilgileri

\begin{tabular}{lcc}
\hline \multicolumn{1}{c}{ Bilgiler } & $\begin{array}{c}\text { Hazine } \\
\text { Taşınmazı }\end{array}$ & $\begin{array}{c}\text { Emsal } \\
\text { Taşınmaz }\end{array}$ \\
\hline Mahalle & Cumhuriyet & Cumhuriyet \\
\hline Ada No & 208 & 208 \\
\hline Parsel No & 45 & 44 \\
\hline Toplam Yüz ölçüm (m²) & 172,078 & 166,94 \\
\hline Satılan Hisse & $2123 / 9216$ & $1 / 2$ \\
\hline Satılan Yüzölçüm & 39,64 & 83,47 \\
\hline Emlak Rayiç Değeri (TL) & 3.479 & 3.479 \\
\hline Satış Yılı & 2017 & 2018 \\
\hline Satış Usulü & Hissedara & \\
\hline Yeniden Değerleme (\%) & Doğrudan & Tapu Satış \\
\hline $\begin{array}{l}\text { 2018 yılıș } \\
\text { Birim Bedeli (TL) }\end{array}$ & 14,47 & \\
\hline
\end{tabular}

Yapılan belirlemeler sonucunda hazine ve emsal taşınmaza ait bilgiler incelenmiştir. Hazine taşınmazının 2123/9216 hissesi, emsal taşınmazın ise $1 / 2$ hissesi satışa konu olmuştur. Her iki taşınmazda kent merkezinde olmakla birlikte şehrin en merkezi konumundadır. Taşınmazlar yan yanadır. İmar planında her iki tașınmazda aynı amaçla ayrılmıștır ve ticaret sahasındadırlar. Bitişik nizam 6 kat inşaat izinleri mevcuttur. Belediye hizmetlerine erişimleri, ulaşım imkânları ve sosyokültürel olanakları şehrin en merkezi konumunda olmalarından ötürü üst seviyededir. Her ikisinin üzerinde yapı bulunmamaktadır. Aynı caddeye cepheleri olduğundan ötürü emlak rayiç değerleri eşit ve 3.479 TL'dir. Ek olarak emsal taşınmazın ana yola cephesinin olmasının yanında tali yola da cephesi bulunmaktadır.

Taşınmazlara ait bilgiler göz önüne alınarak karşılaştırma yapılıp hazine taşınmazının $\mathrm{m}^{2}$ bedelinin emsal taşınmazın $\mathrm{m}^{2}$ bedelinden yüksek olmasının sebepleri irdelenmiștir. Aynı konumda ve yan yana olmaları, imar planında aynı amaca ayrılmış olmaları ve inşaat izin durumlarının da eşit olması, alt yapı hizmetlerine erişimleriyle birlikte ulaşım ve sosyokültürel olanaklardan da eşit derecede faydalanabiliyor olmaları taşınmaz bedellerini de eşit derecede etkilemektedir. Öte yandan emlak rayiç değerleri de eşittir. Ortaya çıkan $\mathrm{m}^{2}$ bedelleri arasındaki farkın hazine taşınmazının bir değerleme uzmanı tarafından bedel tespiti yapılırken, emsal taşınmazın ise gerçek kişilere ait olmasından ötürü bedel tespitinin doğru bir șekilde yapılamamasından kaynaklandı̆̆ kanısına varılmıştır. Son olarak hazine taşınmazının 2017 yılında satılmış olması ve 2018 yılında satılan emsal taşınmazla karşılaștırılırken fiyatının güncellenmesi gerekliliği de hazine taşınmazının $\mathrm{m}^{2}$ bedelini arttıran bir diğer unsurdur.

\subsubsection{Yenicuma Mahallesinde Yapılan Inceleme}

Yenicuma Mahallesinde mülkiyetinin tamamı hazineye ait olan 94,05 m² yüz ölçümlü 226 ada 6 nolu parsel incelenmiştir (Şekil 9 ve Şekil 10). Bu taşınmazın 03.12.2018 tarihindeki tahmin edilen bedel tespit raporuna göre taşınmaz bedeli 188.100,00 TL iken m2 bedeli 2.000 TL olarak belirlenmiştir. Taşınmaz üzerinde muhdesat bulunmamaktadır.

226/6 nolu hazine tașınmazına emsal olarak Ortahisar Tapu Müdürlüğünden temin edilen bilgilerle Yenicuma Mahallesinde 178,25 m2 yüz ölçümlü 226 ada 33 nolu parselin 2018 yılındaki 1/2 hisselik (89,125 m2) satışı belirlenmiştir (Şekil 9 ve Şekil 11). Emsal taşınmaz $\mathrm{m} 2$ fiyatı 544,18 TL olmak üzere $48.500 \mathrm{TL}$ bedel ile satılmıştır.

Mevcut bilgiler ışığında hazine taşınmazının $2.000 \mathrm{TL}$ olan $\mathrm{m}^{2}$ satış bedelinin emsal taşınmazın 544,18 TL olan $\mathrm{m}^{2}$ satış bedelinden \%267,53 daha fazla olduğu anlaşılmıştır. Gerçekleştirilen incelemeler sonucunda hazine ve emsal taşınmazlarına ait elde edilen bilgilere Tablo 4'te yer verilmiştir.

Tablo 4. Yenicuma Mahallesindeki Hazine ve Emsal Taşınmazın Satış Bilgileri

\begin{tabular}{|c|c|c|}
\hline Bilgiler & $\begin{array}{c}\text { Hazine } \\
\text { Tașınmazı }\end{array}$ & $\begin{array}{c}\text { Emsal } \\
\text { Tașınmaz }\end{array}$ \\
\hline Mahalle & Yenicuma & Yenicuma \\
\hline Ada No & 226 & 226 \\
\hline Parsel No & 6 & 33 \\
\hline Toplam Yüz ölçüm (m²) & 94,05 & 178,25 \\
\hline Satılan Hisse & Tamamı & $1 / 2$ \\
\hline Satılan Yüzölçüm & 94,05 & 89,125 \\
\hline Emlak Rayiç Değeri (TL) & 844 & 404 \\
\hline Satış Yılı & 2018 & 2018 \\
\hline Satıș Usulü & Açlk İhale & Tapu Satıș \\
\hline Yeniden Değerleme (\%) & 2.000 & 544,18 \\
\hline $\begin{array}{l}2018 \text { yılı m² } \\
\text { Birim Bedeli (TL) }\end{array}$ & Yenicuma & Yenicuma \\
\hline
\end{tabular}

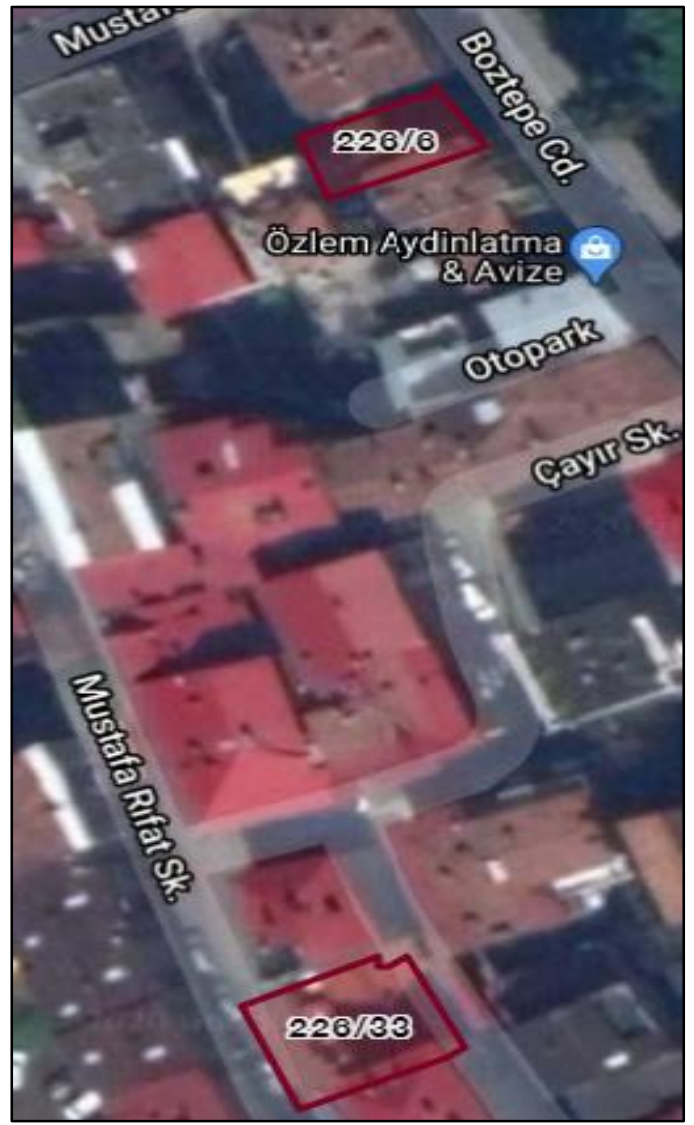

Şekil 9. 226/33 nolu hazine taşınmazının ve 226/6 nolu emsal taşınmazın uydu görüntüsü

Kaynak: https://parselsorgu.tkgm.gov.tr 
Yapılan belirlemeler sonucunda hazine ve emsal taşınmaza ait bilgiler incelenmiștir. Hazine taşınmazının tamamı, emsal tașınmazın ise $1 / 2$ hissesi satıșa konu olmuştur. Hem hazine taşınmazı hem de emsal taşınmaz kent merkezindedir. Taşınmazlar aynı adada olup imar planında iskân sahası içindedirler. Her iki taşınmaz bitişik nizam 4 kat inşaat iznine sahiptir. Belediye hizmetlerine erişimleri, ulaşım imkânları ve sosyokültürel olanakları şehrin merkezi konumunda olmalarından ötürü mevcuttur. Hazine taşınmazının ana yola, emsal taşınmazın tali yola cephesi bulunmaktadır. Hazine tașınmazının 2018 yılı emlak rayiç değeri 844 TL, emsal taşınmazın ise 404 TL olarak tespit edilmiştir. Ek olarak hazine taşınmazının açık ihale satışına çıkarıldığı fakat ihaleye katılım olmadığı belirlenmiştir.

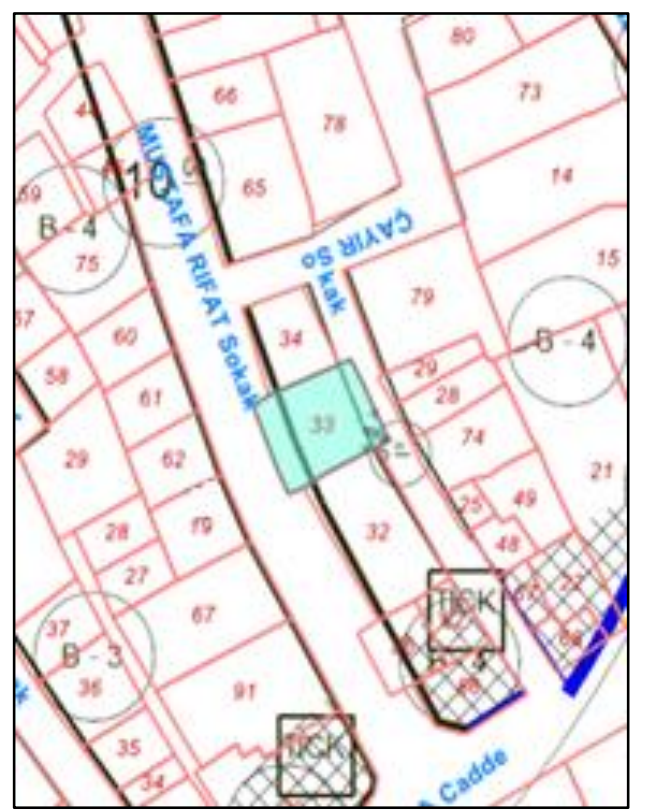

Şekil 10. 226/33 nolu hazine taşınmazının imar planı kesiti

Kaynak: https://kbs.trabzonortahisar.bel.tr/imardurumu/

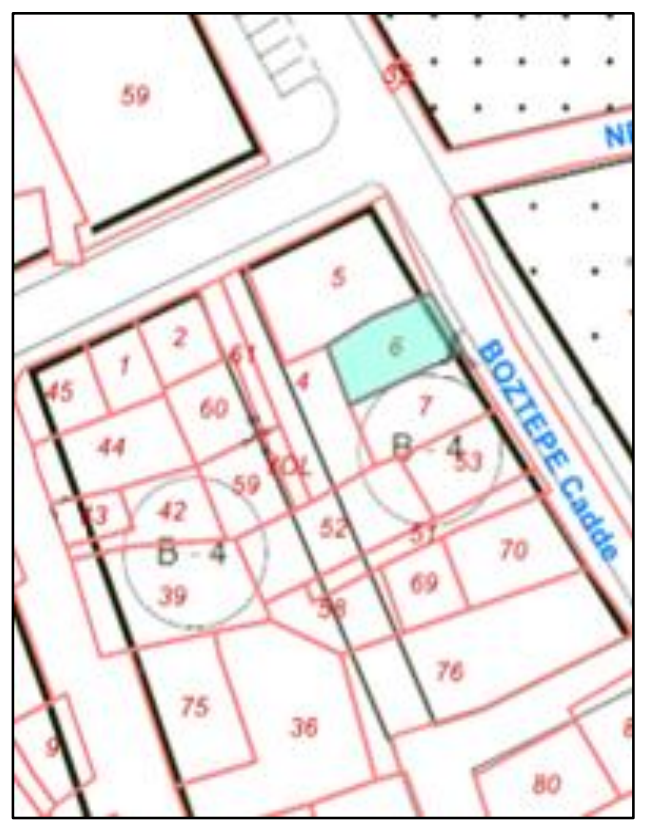

Şekil 11. 226/6 nolu emsal taşınmazın imar planı kesiti Kaynak: https://kbs.trabzonortahisar.bel.tr/imardurumu/
Taşınmazlara ait veriler dikkate alınarak karşılaștırma yapılmıș ve hazine tașınmazının $\mathrm{m}^{2}$ bedelinin emsal taşınmazın $\mathrm{m}^{2}$ bedelinden yüksek olmasının sebepleri irdelenmiștir. Aynı konumda ve aynı adada olmaları, şehir merkezinde olmaları, imar planında aynı amaca ayrılmaları, her iki taşınmazında 4 kat inşaat izninin olması, alt yapı hizmeti olanaklarıyla beraber ulaşım ve sosyokültürel imkânlardan eşit derecede faydalanıyor olmaları taşınmaz bedellerinde eşit derecede etkiye sahiptir. Öte yandan hazine taşınmazının emlak rayiç değerinin emsal taşınmazın emlak rayiç değerinden \%108,91 fazla olduğu anlaşılmıştır. Bu farkın hazine taşınmazının ana yola, emsal taşınmazın ise tali yola cephesi olmasından kaynaklandığı sonucuna varılmıştır. $\mathrm{Bu}$ cephe farkları taşınmazların $\mathrm{m}^{2}$ bedellerine de yansımış ve hazine taşınmazını daha değerli kılmıștır. Diğer taraftan hazine taşınmazın tamamının, emsal taşınmazın ise yarı hissesinin satışa konu olması da fiyatı etkileyen bir unsur olabilir. Son olarak ortaya çıkan $\mathrm{m}^{2}$ bedelleri arasındaki farkın, hazine taşınmazının bir değerleme uzmanı tarafından bedel tespiti yapılırken emsal taşınmazın ise özel kişilere ait olmasından ötürü bedel tespitinin doğru bir şekilde yapılamamasından kaynaklandığı sonucuna varılmıștır.

\section{SONUÇLAR}

Hazine taşınmazları, ülkemizdeki kamu hizmetlerinin yönetilmesi ve bütçeye kaynak sağlaması için yıllardır başvurulmuş olan temel kaynaklardandır. Kamu malları ve hazinenin özel malları olarak iki başlıkta incelenmektedirler. Kamu mallarının kamu hizmetine tahsis edilmesiyle kamu hizmetleri yürütülürken hazinenin özel malları getirmiş olduğu gelirle kamuya yarar sağlamaktadır. Hazine taşınmazları, özellikle değișen ekonomik şartlarda ortaya çıkan taşınmaz ihtiyacının giderilmesinde bir hayli önem kazanmıștır. Bu taşınmazlarının ekonomiye kazandırılması sürecinde bir takım tasarruf faaliyetleri yürütülmektedir. Alımsatım, kira, ecrimisil, trampa, irtifak hakkı ve diğer tasarruf faaliyetleri kapsamında hazine taşınmazları değerleme işlemlerine tabi tutulmaktadır. Değerleme işlemlerinin doğru ve objektif bir şekilde yapılması tasarruf faaliyetlerinin verimli bir șekilde yürütülmesini ve hazinenin hak ve menfaatlerinin korunmasını sağlayacaktır.

Ülkemizin yüz ölçümünün yarısından fazlası hazine taşınmazlarından oluşmaktadır. Hazine taşınmazlarının tasarruf faaliyetleri kapsamında yapılan değerleme çalışmalarının güvenilir ve objektif olması, bu taşınmazların ülke ekonomisine kazanç olarak geri dönmesini mümkün kllacaktır. Aksi hâlde doğru rayiç bedelden uzaklașılmasıyla devlet kazancı düșecektir. Taşınmaz değerleme sürecinde değerlemesi yapılacak taşınmazlar farklı özelliklere sahip olsalar dâhi bu süreçte kullanılan yöntemler belirli bir uluslararası standart çerçevesinde yürütüldüğü takdirde objektif sonuçlara ulaşlabilmektedir. Değerleme sürecinde standartlara uymanın yanında değerlemeyi yapan kişilerin bilgi birikimi ve tecrübeleri de bir o kadar önemlidir. $\mathrm{Bu}$ bağlamda doğru bir rayiç bedele 
ulaşılabilmesi için değerlemenin uzman kişiler tarafindan yapılması daha uygun olacaktır.

Yapılan çalıșma ile tașınmaz değerleme yöntemlerinden biri olan emsal yöntemi temel alınarak hazine taşınmazlarının satışları ile bunlara emsal olan satışlar karşılaştırılmış ve bedele etki eden faktörler irdelenmiştir. Bu bağlamda ele alınan üç bölgenin her biri farklı özelliklere sahiptir. İncelenen ilk bölge olan Sayvan Mahallesi, diğer iki bölgeye kıyasla kent merkezinden uzaktır. Cumhuriyet ve Yenicuma mahalleleri şehir merkezinde olduğundan ötürü belediye ve alt yapı hizmetlerinden, ulașım imkânlarından ve sosyokültürel olanaklardan yararlanırken, Sayvan Mahallesi'nde bu faktörler kısıtlıdır. Tüm bu sebepler, Sayvan Mahallesinde incelenmiş olan taşınmazların bedellerine yansımış ve diğer iki inceleme bölgesine kıyasla satış bedellerine yansıyan değer düşüklüğü gözlemlenmiștir.

İkinci bölge olan Cumhuriyet Mahallesi'yle üçüncü bölge olan Yenicuma Mahallesi ise şehir merkezinde olup, belediye ve alt yapı hizmetlerinden, ulaşım imkânlarından ve sosyokültürel olanaklardan eşit derecede yararlanmaktadırlar. Ancak Cumhuriyet Mahallesi, Yenicuma Mahallesi'ne kıyasla şehrin en merkezi konumunda olmasından ötürü taşınmaz bedelleri daha yüksektir. $\mathrm{Bu}$ durum incelenen taşınmazlardaki satış bedellerine yansımıștır. Ek olarak imar durumları kiyaslandığında Cumhuriyet Mahallesi'nde incelenen taşınmazların bitișik nizam 6 kat inşaat iznine sahipken Yenicuma Mahallesinde incelenen taşınmazların bitişik nizam 4 kat izne tabi tutulması sonucunda oluşan farklılık, Cumhuriyet Mahallesi'nde incelenen taşınmazların bedellerine olumlu katkı sağlamıştır. Bu farklar emlak vergi değerlerine de etki etmiş ve Cumhuriyet Mahallesi'ndeki taşınmazları daha değerli kılmıștır. Öte yandan Cumhuriyet Mahallesi'nde incelenen tașınmazların imar planında ticaret sahasında olmaları, iskân sahasında olan Yenicuma Mahallesindeki taşınmazlara göre daha avantajlı olmuş ve bu da bedellerde fark yaratmıștır.

Satışların açık ihale usulüyle yapılmasının da bedel arttıran durumlardan biri olduğu kanısına varılmıştır. Açık ihale usulü yapılan satışlarda rekabetten ötürü taşınmaz bedellerinde yüksek miktarda artışlarla karşılașılabilmektedir.

Tüm bu bedel farklılıklarında değerlemenin uzman kişiler tarafından yapılıp yapılmadığı da büyük bir önem taşımaktadır. Bu alanda uzman olan kişilerin değerleme standartlarını da gözeterek değerleme çalışmalarını yürütmesi, güvenilir sonuçlar alabilmek için en doğru yaklaşımdır. Yapılan çalışmadan da anlaşıldığı üzere her bölgede incelenen taşınmazlar aynı kriterlere eşit ya da yakın derecede sahip olsalar dâhi, emsal taşınmazların özel kişilere ait olup değerlerinin uzman kişiler tarafından belirlenmemiş olması, hazine taşınmazlarının satış bedelleriyle arasında büyük farklar meydana getirmiştir. Bu farklar da hazine taşınmaz bedelleri ile emsal taşınmaz bedelleri arasındaki en belirgin değer farkını göz önüne sermektedir. Dolayısıyla verilere ulaşmak önemli olduğu kadar bu verilerden doğru bir şekilde yararlanabilmek ve bedele yansıtabilmek de çok mühimdir.

Hazine taşınmazları ile emsal taşınmaz bedellerinin daha objektif bir şekilde belirlenebilmesi adına farklı kurum ve kuruluşlardan, gayrimenkul değerleme uzmanlarından ve internet ortamından alınan verilerin bir araya toplanıp birbiriyle entegre olabildiği dinamik bir veri bankası oluşturulması ve bu sistemin değerleme çalışmalarına temel olması, değerleme çalışmalarının doğruluğu ve objektifliği açısından önerilmektedir. Hazine taşınmazlarının değerlemesi kapsamında yapılacak olan tüm iyileştirmeler, bu taşınmazların ülke ekonomisine kazandırılmasında güçlü adımlar olacaktır.

\section{ARAŞTIRMACILARIN KATKI ORANI}

H. Ebru Çolak: Veri Toplama, Araştırma, Düzenleme, Tuğba Memişoğlu: Veri Toplama, Araştırma, Makale Yazma, Düzenleme, Nihal Genç: Araștırma, Makale Yazma, Düzenleme

\section{ÇATIŞMA BEYANI}

Herhangi bir çıkar çatışması bulunmamaktadır.

\section{KAYNAKÇA}

Aliefendioğlu Y \& Aksu N (2017). Hazine Taşınmazlarının Ekonomiye Kazandırılma Yöntemleri Ve Uygulamalarının Değerlendirilmesi. Kastamonu Üniversitesi Íktisadi ve İdari Bilimler Fakültesi Dergisi, 17, (3).

Aliefendioğlu Y \& Turgut C (2018). Vakıf Taşınmazların Kira Bedellerinin Tespitinde Karşılaşılan Sorunların Analizi. Vakıflar Dergisi, 116-129.

Atılgan Y (2010). Hazine Taşınmaz Mallarının Değerlemesi ve Türkiye Ekonomisine Etkileri. İstanbul Üniversitesi Sosyal Bilimler Enstitüsü, Yüksek Lisans Tezi İstanbul.

Çoruhlu Y \& Demir $O$ (2014). Trabzon Ayasofya Camii ' nin "Mülkiyet Hakkı" Üzerine Bir İnceleme. Vakıflar Dergisi, 42, 89-98.

Karaca H (2008). Taşınmaz Mal Değerlemesi Yöntemleri ve Karşılaştırılması. İstanbul Teknik Üniversitesi, Fen Bilimleri Enstitüsü, Yüksek Lisans Tezi, İstanbul.

Kuşgöz C (2018). Hazine Taşınmazlarının Yönetim Şekilleri ve Değerlemesi. Marmara Üniversitesi Sosyal Bilimler Enstitüsü, Yüksek Lisans Tezi, İstanbul.

Milli Emlak Genel Müdürlüğü (2014). Hazine Taşınmazlarının Değerleme Isşlemleri. Genelge, Ankara.

Milli Emlak Genel Müdürlüğü (2018). 2018 Faaliyet Raporu. Ankara.

Milli Emlak Genel Müdürlüğü (2018). Hazine Taşınmazlarının Kiraya Verilmesi İşlemleri El Rehberi. Ankara.

Milli Emlak Genel Müdürlüğü (2019). 2019 Faaliyet Raporu. Ankara.

Söyler İ (2005). Devlet Mallarının Kamu Finansmanı Açısından Değerlendirilmesi, İstanbul Üniversitesi Sosyal Bilimler Enstitüsü, Doktora Tezi,İstanbul.

T.C. Resmi Gazete. (1987). Kadastro Kanunu. https://www.resmigazete.gov.tr/ Erişim Tarihi: 25.08.2020.

T.C. Resmi Gazete. (2006). Kamu Idarelerine Ait Taşınmazların Tahsis ve Devri Hakkında Yönetmelik. 
https://www.resmigazete.gov.tr/ Erişim Tarihi: 26.08.2020.

T.C. Resmi Gazete. (2007). Hazine Taşınmazlarının Idaresi Hakkında Yönetmelik. https://www.resmigazete.gov.tr / Erişim Tarihi: 26.08.2020.

T.C. Resmi Gazete. (2010). 327 sira nolu Milli Emlak Genel Tebliği. https://www.resmigazete.gov.tr/ Erişim Tarihi: 01.09.2020.
Tanrıvermiş H (2017). Gayrimenkul Değerleme Esasları. Ankara: Lisanslama Sınavları Çalışma Kitapları.

Yılmaz M (2019). Gayrimenkul Değerleme Yöntemleri ve Bir Uygulama. Marmara Üniversitesi, Sosyal Bilimler Enstitüsü, Yüksek Lisans Tezi, İstanbul.

Yomralıoğlu T, Nişancı R, Çete M \& Candaş E (2011). Dünya'da ve Türkiye'de Taşınmaz Değerlemesi, Türkiye'de Sürdürülebilir Arazi Yönetimi Çalıştayı, 26-27 Mayıs, Okan Üniversitesi, İstanbul. 